\title{
Possible Somatic Mosaicism of Novel FUS Variant in Familial Amyotrophic Lateral Sclerosis
}

Shin Hisahara, MD, PhD, Ayumi Nishiyama, MD, PhD, Emiko Tsuda, MD, PhD, Syuuichirou Suzuki, MD, PhD, Akihiro Matsumura, MD, PhD, Aki Ishikawa, MD, PhD, Akihiro Sakurai, MD, PhD, Ikuko N. Motoike, PhD, Masashi Aoki, MD, PhD, Yoko Aoki, MD, PhD, and Shun Shimohama, MD, PhD

Neurol Genet 2021;7:e552. doi:10.1212/NXG.0000000000000552

Fused-in-sarcoma (FUS) mutation is associated with a familial amyotrophic lateral sclerosis (fALS) characterized by early onset and rapid progression. Here, the authors describe a rare case of possible somatic mosaicism of a novel FUS variant for a fALS family with intrafamilial clinical variablity.

\section{Cases}

\section{Case 1}

The index case (II-6, figure, A) was a woman who had gradual weight loss and gait disorder from age 44 years. Two years later, she could not walk without assistance. Neurologic examination at age 46 revealed tongue atrophy and fasciculation, together with weakness and fasciculation in her limbs and trunk. Pathologic reflexes were observed bilaterally. Needle EMG showed active and chronic neurologic changes in multiple regions, suggesting ALS. Enteral nutrition with percutaneous endoscopic gastrostomy were started at age 47, and artificial ventilation with tracheostomy at age 50 .

\section{Case 2}

The son of the index case (III-5, figure, A) was born by full-term normal delivery. His psychomotor milestones were normal. At age 11 years, he had difficulty standing from a squatting position. At age 12, he was seen by a pediatrician because of his inability to walk. Neurologic examination indicated muscle weakness in his limbs. Increased deep tendon reflexes were observed. Muscle biopsy was performed twice, with results indicating neurogenic diseases including ALS rather than myopathies. He complained of respiratory distress 2 months later and required tracheostomy and artificial ventilation at 6 months after admission. Six months later, he was in a complete locked-in state. He died at the age of 33.

Whole exome analysis using a blood sample from Case 2 identified a novel heterozygous FUS variant (c. 1,542_1545delGGGT, p.Gly515Serfs13*) (figure, A and B). Surprisingly, it was difficult to detect the same variant in the blood sample of case 1 because of the low frequency of the mutant allele; only $1 / 30$ reads counted using the Integrative Genomics Viewer (figure e-1, links.lww.com/NXG/A363). The targeted next generation sequencing (NGS) data from her peripheral blood and saliva showed repeatable low variant rates of 4/327 and 5/280 reads, respectively. Sanger sequencing confirmed that the mother had lower mutant allele fraction in blood than her son (figure, B). Furthermore, higher mutant allele fractions were detected in her hair and nail than blood and saliva (figure, B).

\author{
Correspondence \\ Dr. Hisahara \\ hisahara@sapmed.ac.jp
}

\section{RELATED ARTICLE}

\section{Editorial}

Does Somatic Mosaicism Account for Some Sporadic ALS?

Page e555

From the Department of Neurology (S.H., S. Suzuki, A.M., S. Shimohama), School of Medicine, Sapporo Medical University, Japan; Department of Neurology (A.N., M.A.), Tohoku University School of Medicine, Sendai, Japan; Department of Neurology (E.T.), Sapporo Shirakabadai Hospital, Japan; Department of Medical Genetics and Genomics (A.I., A.S.), School of Medicine, Sapporo Medical University, Japan; Tohoku Medical Megabank Organization (I.N.M.), Tohoku University Graduate School of Information Sciences, Sendai, Japan; and Department of Medical Genetics (Y.A.), Tohoku University School of Medicine, Sendai, Japan.

Go to Neurology.org/NG for full disclosures. Funding information is provided the end of the article. 
Figure Somatic Mosaicism of FUS Variant Causing Familial Amyotrophic Lateral Sclerosis With Different Clinical Courses Within the Family (A) Pedigree of the Family

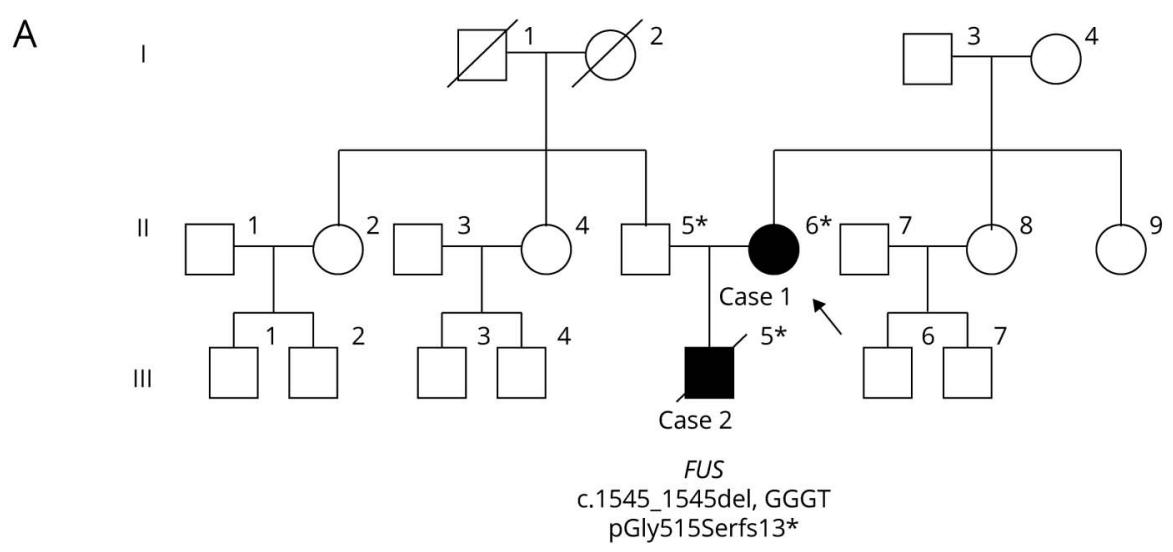

B
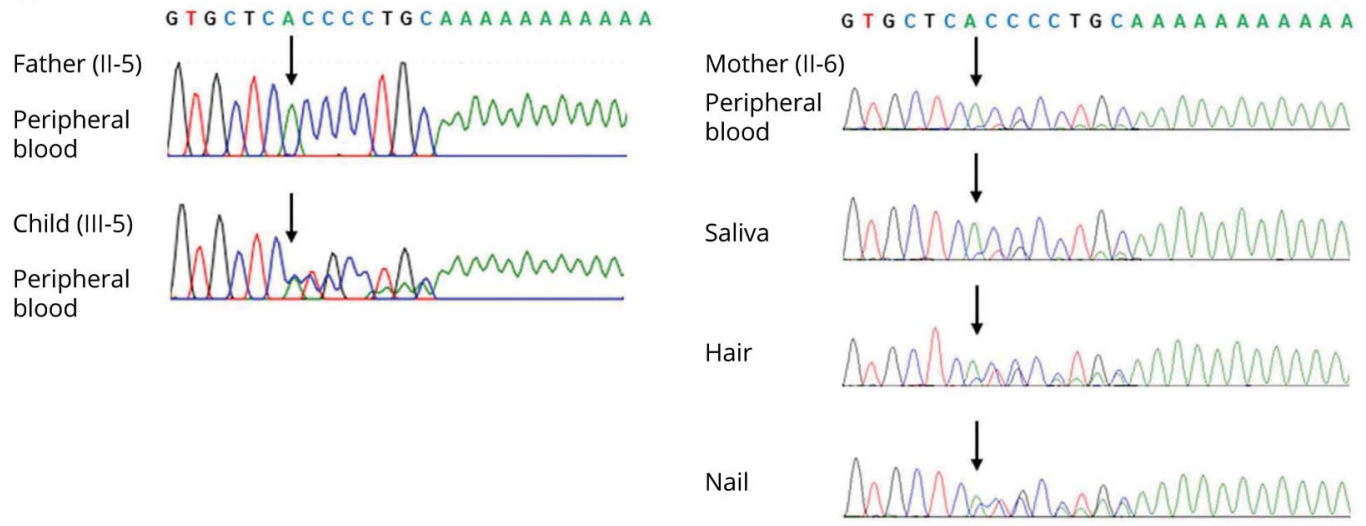

Black symbols indicate individuals affected by amyotrophic lateral sclerosis. Asterisks indicate individuals whose DNA was studied. Case 1 (II-6) is the index patient (arrow) with mosaic variant of FUS. (B) Sanger sequencing of DNA from peripheral blood of the unaffected father (II-5) shows wild type. Sanger sequencing of DNA from peripheral blood of case 2 (III-5) clearly shows a heterozygous FUS variant (c.1542_1545delGGGT, p.Gly515Serfs13*). Sanger sequencing of DNA from peripheral blood, saliva, hair, and nail samples of case 1 (II-6) confirms different frequencies of FUS mutant allele in various tissues. Black arrows indicate start of deletion. Sequencing results are shown in reverse. Supplementary data and table, links.Iww.com/NXG/A369 contain additional details on the methodology. FUS = Fused-in-sarcoma.

\section{Discussion}

We present a rare case of a possible somatic and germline mosaic variant in a patient with fALS. Sequencing confirmed lower mutant allele fraction in blood cells of the index case than her son. The index case also had different mutant allele fractions in various tissues. These observations indicate that she has a somatic variant of FUS across multiple tissues, which affects germline and somatic cells. This variant may have arisen before the 3 germ layers split, which could lead to mosaicism not restricted to the ectoderm, with lower but equivalent proportion of variant both in the mesoderm-derived blood and mesoderm- and ectoderm-derived saliva. Whether she had mosaicism in the CNS could not be investigated. However, given the higher variant fractions in tissues such as nail from the ectoderm system, a similar tendency may be found in neural tissues. Targeted deep sequencing in trio analysis revealed $\sim 3 \%$ of causative de novo mutations display postzygotic mosaicism. ${ }^{1}$
Her son showed more severe clinical course with juvenile onset and rapid progression. Recently, we found genetic linkage in $49.5 \%$ of a Japanese cohort of familial ALS. ${ }^{2}$ Most of the FUS-linked patients with fALS showed phenotype characterized by early onset, in contrast to patients with sporadic ALS. ${ }^{3}$ The variant p.G515Sfs $13^{*}$ is located in the highly conserved C terminal of FUS protein, where most of the FUS variants have been identified. The mutant protein has a truncated peptide from 515 to 526 amino acids, which coincides with the mutant terminal peptides affected by p.R495QfsX527 variant. ${ }^{4}$ The degree of FUS protein mislocalization from nucleus to cytoplasm by C-terminal deletion correlates with the severity of clinical phenotype. ${ }^{5}$ However, variable phenotypes of the same FUS variant have been observed. ${ }^{4}$

Somatic mosaicism in ALS is probably rare, but this possibility should be considered. Several studies indicated somatic variant in other neurodegenerative disorders such as Alzheimer's disease. ${ }^{6}$ The clinical course of case 1 suggests that somatic 
variant may have a milder phenotype depending on the extent of mosaicism. In ALS, repeat expansions of C9ORF72 exhibit both infrafamilial and somatic instability leading to mosaicism. ${ }^{7}$ In patients with intrafamilial variability or apparently sporadic disease, it may be important to suspect somatic mosaic variants during screening for candidate variants using high coverage NGS. Furthermore, variant analysis using multiple tissues other than peripheral blood may help identify low-level mosaicism. Additional studies including histopathology of these cases would contribute to elucidate the pathogenesis of ALS.

\section{Study Funding}

This research was supported by Initiative on Rare and Undiagnosed Diseases (IRUD) and JSPS KAKENHI Grant Number JP19K16997. This study was also supported in part by the Grant-in-Aid for Exploratory Research, grants from Smoking Research Foundation Grant Number 2049151 and by JSPS KAKENHI Grant Number 16H05279, JSPS KAKENHI Grant Number 17H07099, JSPS KAKENHI Grant Number 17K09783, JSPS KAKENHI Grant Number 15K19288, JSPS KAKENHI Grant Number 16K19776, and JSPS KAKENHI Grant Number 15K09840.

\section{Disclosure}

The authors report no relevant disclosures. Go to Neurology. org/NG for full disclosures.

\section{Publication History}

Received by Neurology: Genetics July 29, 2020. Accepted in final form November 9, 2020.

\section{Appendix Authors}

\begin{tabular}{lll}
\hline Name & Location & Contribution \\
\hline $\begin{array}{l}\text { Shin } \\
\text { Hisahara, } \\
\text { MD, PhD }\end{array}$ & $\begin{array}{l}\text { Sapporo Medical } \\
\text { University, Sapporo, } \\
\text { Japan }\end{array}$ & $\begin{array}{l}\text { Designed and conceptualized } \\
\text { study and drafted the } \\
\text { manuscript }\end{array}$ \\
\hline $\begin{array}{l}\text { Ayumi } \\
\text { Nishiyama, } \\
\text { MD, PhD }\end{array}$ & Tohoku University, & $\begin{array}{l}\text { Performed analysis, } \\
\text { interpreted the data, and } \\
\text { drafted the manuscript }\end{array}$ \\
\hline $\begin{array}{l}\text { Emiko Tsuda, Japan } \\
\text { MD, PhD }\end{array}$ & $\begin{array}{l}\text { Sapporo Shirakabadai } \\
\text { Hospital, Sapporo, Japan }\end{array}$ & Provided clinical information \\
\hline
\end{tabular}

Appendix (continued)

\begin{tabular}{|c|c|c|}
\hline Name & Location & Contribution \\
\hline $\begin{array}{l}\text { Syuuichirou } \\
\text { Suzuki, MD, } \\
\text { PhD }\end{array}$ & $\begin{array}{l}\text { Sapporo Medical } \\
\text { University, Sapporo, } \\
\text { Japan }\end{array}$ & Provided clinical information \\
\hline $\begin{array}{l}\text { Akihiro } \\
\text { Matsumura, } \\
\text { MD, PhD }\end{array}$ & $\begin{array}{l}\text { Sapporo Medical } \\
\text { University, Sapporo, } \\
\text { Japan }\end{array}$ & Provided clinical information \\
\hline $\begin{array}{l}\text { Aki } \\
\text { Ishikawa, } \\
\text { MD, PhD }\end{array}$ & $\begin{array}{l}\text { Sapporo Medical } \\
\text { University, Sapporo, } \\
\text { Japan }\end{array}$ & $\begin{array}{l}\text { Performed genetic } \\
\text { consultation }\end{array}$ \\
\hline $\begin{array}{l}\text { Akihiro } \\
\text { Sakurai, MD, } \\
\text { PhD }\end{array}$ & $\begin{array}{l}\text { Sapporo Medical } \\
\text { University, Sapporo, } \\
\text { Japan }\end{array}$ & $\begin{array}{l}\text { Performed genetic } \\
\text { consultation, supervised the } \\
\text { study }\end{array}$ \\
\hline $\begin{array}{l}\text { Ikuko N. } \\
\text { Motoike, } \\
\text { PhD }\end{array}$ & $\begin{array}{l}\text { Tohoku Medical } \\
\text { Megabank } \\
\text { Organization, Sendai, } \\
\text { Japan }\end{array}$ & $\begin{array}{l}\text { Performed analysis and } \\
\text { acquisition of data }\end{array}$ \\
\hline $\begin{array}{l}\text { Masashi } \\
\text { Aoki, MD, } \\
\text { PhD }\end{array}$ & $\begin{array}{l}\text { Tohoku University, } \\
\text { Sendai, Japan }\end{array}$ & $\begin{array}{l}\text { Supervised the study and } \\
\text { obtained funding }\end{array}$ \\
\hline $\begin{array}{l}\text { Yoko Aoki, } \\
\text { MD, PhD }\end{array}$ & $\begin{array}{l}\text { Tohoku University, } \\
\text { Sendai, Japan }\end{array}$ & $\begin{array}{l}\text { Supervised genomic analyses, } \\
\text { and critically revised the } \\
\text { manuscript }\end{array}$ \\
\hline $\begin{array}{l}\text { Shun } \\
\text { Shimohama, } \\
\text { MD, PhD }\end{array}$ & $\begin{array}{l}\text { Sapporo Medical } \\
\text { University, Sapporo, } \\
\text { Japan }\end{array}$ & $\begin{array}{l}\text { Supervised the study, } \\
\text { critically revised the } \\
\text { manuscript, and obtained } \\
\text { funding }\end{array}$ \\
\hline
\end{tabular}

\section{References}

1. Wright CF, Prigmore E, Rajan D, et al. Clinically-relevant postzygotic mosaicism in parents and children with developmental disorders in trio exome sequencing data. Nat Commun 2019;10:2985

2. Nishiyama A, Niihori T, Warita $\mathrm{H}$, et al. Comprehensive targeted next-generation sequencing in Japanese familial amyotrophic lateral sclerosis. Neurobiol Aging 2017; 53:194.e191-194.e198.

3. Akiyama $\mathrm{T}$, Warita $\mathrm{H}$, Kato $\mathrm{M}$, et al. Genotype-phenotype relationships in familial amyotrophic lateral sclerosis with FUS/TLS mutations in Japan. Muscle Nerve 2016; 54:398-404.

4. Belzil VV, Langlais JS, Daoud H, Dion PA, Brais B, Rouleau GA. Novel FUS deletion in a patient with juvenile amyotrophic lateral sclerosis. Arch Neurol 2012;69:653-656.

5. Dormann D, Rodde R, Edbauer D, et al. ALS-associated fused in sarcoma (FUS) mutations disrupt Transportin-mediated nuclear import. EMBO J 2010;29: 2841-2857.

6. Proukakis C. Somatic mutations in neurodegeneration: an update. Neurobiol Dis 2020;144:105021.

7. Gijselinck I, Van Mossevelde S, van der Zee J, et al. The C9orf72 repeat size correlates with onset age of disease, DNA methylation and transcriptional downregulation of the promoter. Mol Psychiatry 2016;21:1112-1124. 


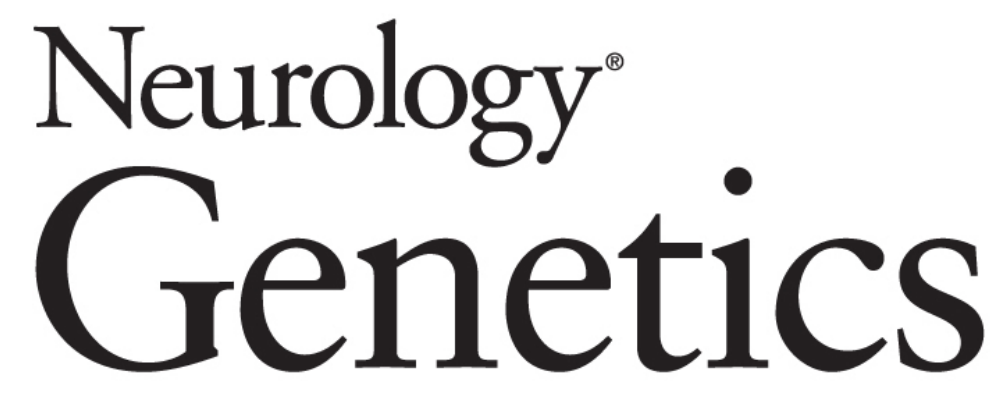

\section{Possible Somatic Mosaicism of Novel FUS Variant in Familial Amyotrophic Lateral Sclerosis \\ Shin Hisahara, Ayumi Nishiyama, Emiko Tsuda, et al. \\ Neurol Genet 2021;7; \\ DOI 10.1212/NXG.0000000000000552}

This information is current as of January 12, 2021

\section{Updated Information \& Services}

References

Subspecialty Collections

Permissions \& Licensing

Reprints including high resolution figures, can be found at: http://ng.neurology.org/content/7/1/e552.full.html

This article cites 7 articles, 1 of which you can access for free at: http://ng.neurology.org/content/7/1/e552.full.html\#\#ref-list-1

This article, along with others on similar topics, appears in the following collection(s):

All Clinical Neurology

http://ng.neurology.org//cgi/collection/all_clinical_neurology All Genetics

http://ng.neurology.org//cgi/collection/all_genetics

Amyotrophic lateral sclerosis

http://ng.neurology.org//cgi/collection/amyotrophic_lateral_sclerosis_

Information about reproducing this article in parts (figures,tables) or in its entirety can be found online at:

http://ng.neurology.org/misc/about.xhtml\#permissions

Information about ordering reprints can be found online:

http://ng.neurology.org/misc/addir.xhtml\#reprintsus

Neurol Genet is an official journal of the American Academy of Neurology. Published since April 2015, it is an open-access, online-only, continuous publication journal. Copyright Copyright $\odot 2021$ The Author(s). Published by Wolters Kluwer Health, Inc. on behalf of the American Academy of Neurology.. All rights reserved. Online ISSN: 2376-7839.

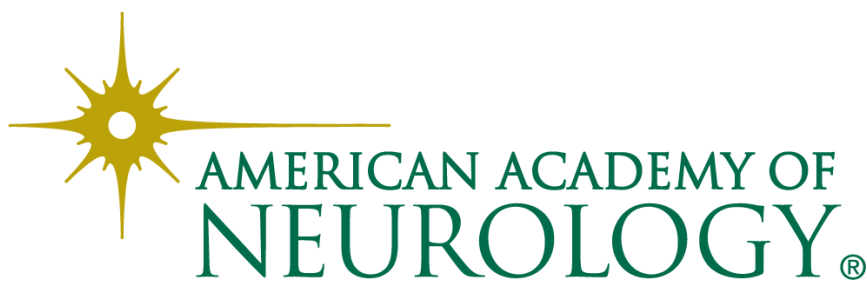

